\title{
Internal Aspects of National Security: Lithuanian Case
}

\author{
Jadvyga ČIBURIENE் $\dot{1}^{1}$ Jūratė GUŠČINSKIENĖ $\dot{2}^{2}$
}

\author{
${ }^{1}$ The School of Economics and Business, Kaunas University of Technology, Gedimino st. 50, LT- \\ 44239 Kaunas, Lithuania \\ ${ }^{2}$ Department of Management, General Jonas Žemaitis Academy of Lithuania, Šilo st. 5A, LT-10322 \\ Vilnius, Lithuania \\ E-mails: ${ }^{1}$ jadvyga.ciburienel@ktu.lt; ${ }^{2}$ jurate.guscinskiene@lka.lt
}

\begin{abstract}
The problem of national security is relevant to all countries of the world as it is an important condition for the country's economic growth. This is confirmed by the World Economic Forum (WEF) distinguished risks of economic development, their interactions, threats and dangers on the global level. The aim of the article is to characterize the internal factors of Lithuanian national security which are related to the possibilities of economic threats and dangers. The method of basic indicator comparison is used; where as the first year (e.g., year 2007) of the analyzed period is selected as the base year. Both absolute and relative quantities of analyzed indices are compared.
\end{abstract}

KEY WORDS: national defence; state budget; emigration; shadow economy, wage level; unemployment level; regions of Lithuania

\section{Introduction}

Threats and dangers to economic development impact negatively on the results of the development of the country or region. Therefore they need to be analyzed and measures should be taken in order to regulate them. Hazards are counterproductive to security, and only reducing economic losses can ensure greater economic security in the country and achieve more robust economic growth. In general as challenges to National defence the current geopolitical risks of the concrete region and the centers of global power are analyzed. Mostly scientific studies of National defence focus on two interrelated aspects: political (cybercrime, civil wars, terrorism, religious extremism) and economic, using comparative research of countries relations [1,2]. Another aspects of studies are: the main driving factors of secure and sustainable development and economic growth, such as foreign direct investment, education [3], energy security, including renewable and the integration energy systems $[4,5]$, identifying economic sectors which have an important effect to the national security (e. g., production and supply of electric energy, natural gas, telecommunications, communications, rail and road transport, water supply, banking sector, etc. activities) [6, 7]. However, for all challenges to national security sufficient state budget revenues are especially important which are needed to finance solving different problems and unexpected dangerous situations. The state budget revenue is negatively affected mostly by unemployment and emigration.

The aim of this study is to analyze and to evaluate the factors that reduce the revenue of the state budget, i.e. the problems of high unemployment level and emigration, as the biggest threat to national security.

The investigation of these factors is compared with the average results in the European Union Member States (EU27) in the period of the year 2007-2016. Both absolute and relative amounts of analyzed indicators are compared. The method of base indicators comparison is used, whereas the first year (e.g., year 2007) of the analyzed period is chosen as the base year. The results of the theoretical research part are characterized with statistical indicators and the theoretical predictions made are checked with practical research.

Method of investigation. The estimation of the main factors that reduce the revenue of the state budget in Lithuania is used, giving the theoretical and practical research. The study was carried out using qualitative methods: scientific literature analysis, statistical data classification, systematization, synthesis, comparison, generalization and illustration, e.g., table and graphical analysis. For the evaluation of the challenges to national defence in the period of year 2007-2016 year 2007 was chosen as the base.

\section{Internal Factors of National Security}

In research regular emphasis is placed on economic growth, its indicators and factors $[8 ; 9 ; 10 ; 11 ; 12]$. It is important to note that scientific literature is still not sufficiently focused on the risks, threats and dangers of economic growth and national security $[13 ; 14]$. In most cases, macroeconomic indicators that address macroeconomic problems: the inflation $[11 ; 12 ; 15]$, the unemployment rate $(16 ; 17)$, the inequality of income inequities $[18 ; 19 ; 20 ; 21]$, the shadow economy

Corresponding author. Tel.: 370-37-300-550.

E-mail address: jadvyga.ciburiene@ktu.lt 
$[22,23]$, etc. are analyzed in scientific literature. At the present time, the World Economic Forum (WEF) presented the evaluation of global threats and revealed areas that can shape global threats for the upcoming in the nearest ten years. The five biggest risks are most widely discussed [24]:

1. Current weak growth in the period after the global financial crisis (more than eight years after the global financial crisis, growth remains weak and discontent high);

2. The current quick technological changes, the 4th Industrial revolution, driven by the development and increased efficiency of digital technologies in manufacturing and services. Increasing operational efficiency increases tension in the labor market, especially in the low-skilled segment of the workforce;

3. Income inequality and "increasing polarization" of population incomes (was ranked by the WEF as the third most important trend for the next 10 years and was cited by almost a third of respondents);

4. Geopolitical threats, such as uncertainties between Russia and NATO; the threat of terrorism; Russia, South Africa, Burundi and the Gambia withdraw from the International Criminal Court, accusing it of unilateralism and ineffectiveness. Geopolitical threats reduce national confidence in the international arena and commitment to international cooperation;

5. Climate change. A great deal of attention is paid to environmental risks, as they are likely to cause potential threats and cause economic losses, and that it is likely that the negative consequences may be higher than before.

Research from WEF [26] suggests that economic development processes are often exposed not only to individual risks, but also to several immediate risks or so-called "risk" interactions. These risk interactions in individual sectors or domains tend to be a long-term, constantly changing process, five of which are presented in Table 1.

Table 1 shows two important risks: 1) large-scale involuntary migration and 2) state collapse or crisis causes a longterm tendency, which is defined as a trend of rising income and wealth in the country, region or globally. This tendency has a negative impact on the country's labor market, population's standard of living, society as a whole and economy. It negatively affects other indicators of public welfare in the country, such as education level, health status, etc. These negative changes mostly affect the population with the lowest income and living below the poverty line. Another important trend - the changing climate - is the consequence of: 1) failure to adapt to climate change and 2) water crises. Changes in climate conditions often lead to undesirable shocks in agricultural products and raw materials, adversely affecting the economy of both a country and the rest of the world. The third trend - the increasing polarization of societies is caused by: 1) interstate conflict with regional consequences and 2) large-scale involuntary migration. The polarization of societies additionally depends on changes in gross domestic product (GDP), household characteristics (place of residence, number of children in the family, education, state of health, etc.).

The main trends of economic development and interconnections of most important risks [25; 26]

Table 1

\begin{tabular}{|c|l|l|}
\hline Number & Trends of country, region or globally & \multicolumn{1}{|c|}{ Risks } \\
\hline 1. & Rising income and wealth disparity & $\begin{array}{l}\text { Large-scale involuntary migration; } \\
\text { State collapse or crisis. }\end{array}$ \\
\hline 2. & Changing climate & $\begin{array}{l}\text { Failure of climate-change mitigation and adaption; } \\
\text { Water crises. }\end{array}$ \\
\hline 3. & Increasing polarization of societies & $\begin{array}{l}\text { Interstate conflict with regional consequences; } \\
\text { Large-scale involuntary migration. }\end{array}$ \\
\hline 4. & Profound social instability & $\begin{array}{l}\text { Failure of national governance; } \\
\text { Profound social instability. }\end{array}$ \\
\hline 5. & Ageing population & $\begin{array}{l}\text { Unemployment; } \\
\text { Profound social instability. }\end{array}$ \\
\hline
\end{tabular}

Economic threats are a potential opportunity to suffer losses to the subject of a relevant economic activity (at the microeconomic, mesoeconomic or macroeconomic level) due to specific internal or external factors. The impact of threats is of a potential nature and always depends on the interaction of various factors (internal, external). Dangers are understood as a specific probability of a threat.

Scientific research [13] emphasizes that the concept of security is anonymity of insecurity. Insecurity caused by any factor is a threat to an entity analyzed at any level (microeconomic, mesoeconomic or macroeconomic).

Internal threats to national security can be classified according to various criteria:

1) according to the source criterion, they may be: military, economic, political, social, legal, ecological, energy related, informational, moral, management, etc.;

2) according to the field/area of influence, they can also be assigned to: military, economic, political, social, legal, ecological, energy, informational, moral, management, etc .;

3) according to nature they may be: nature or natural (e. g. earthquake, tsunami, drought, rainstorms, epidemics of various diseases, etc.) and of social origin (for example, a major chemical plant, nuclear power plant accident and disruption of operation, harmful to health and / etc.);

4) according to the duration or time factor they may be: temporary and permanent (depending on the type of operation of the acting agent).

Practical experience of a wide range of problems suggests that various threats must be addressed without waiting until they are even more acute and affect society in multiple ways [25]. The key measures are to increasee employment and 
reduce unemployment, the level of discomfort, number of people at risk of poverty and social exclusion in the country and the incidence of poverty. The use of economic, social, cultural and value tools to solve various problems promotes the emergence of various synergistic effects

\section{Results}

The paper summarized the scientific literature on the topic of challenges to national defence and analyzed the internal security threats in Lithuania. The main internal economic factors affecting country development are: unemployment and emigration. Seeking to reduce shadow economy and to increase the wage level gives an impetus to be in the line with the EU-28 government budget indicators and to create preconditions for more reliable national security in Lithuania and its regions. The comparison of the situation in Lithuania and the EU-27 allows to determine the direction and the rate of changes of economic indicators and to compare with expectations of population.

The main characteristics of Lithuanian economic development in the year 2007-2016 are given and compared with the average data of the EU-27 in Table 2. It is important that inflation measured as GDP deflator, in Lithuania increased in the period of 2007-2008, after which it was reduced to an acceptable level in 2016, as shown in Table 2. In Lithuania inflation achieved $1.0 \%$ level in 2016; in the EU-27 in the same year it was considerably smaller $-0.8 \%$. The discomfort index, as a sum of inflation and unemployment level, has increased after the financial crisis in Lithuania after year 2007. This growth was mainly caused due to the growth of unemployment. The discomfort index in Lithuania was higher than in the EU-27 in the year 2007-2014. After 2008 financial crisis and 2012 recession, the risk of poverty and exclusion was constantly increasing until 2012 in Lithuania. The changes of poverty are described by the indicator risk of poverty of social exclusion, in percent. The risk of poverty coefficient, as it shown in Table 2, has dramatically increased in Lithuania since 2008 and in 2010 was accordingly $34.0 \%$ when in the EU-27 it was $23.7 \%$.

The changes of social development indicators in the period 2007-2016[27]

Table 2

\begin{tabular}{|c|c|c|c|c|c|c|c|c|c|c|c|}
\hline Indicator/Year & 2007 & 2008 & 2009 & 2010 & 2011 & 2012 & 2013 & 2014 & 2015 & 2016 & $\begin{array}{l}\text { Growth } \\
\text { rate } \\
2007- \\
2016, \%\end{array}$ \\
\hline \multicolumn{12}{|c|}{ 1.Inflation (according GDP deflator), \% } \\
\hline -Lithuania & 8.6 & 9.7 & -3.3 & 2.4 & 5.2 & 2.7 & 1.3 & 1.1 & 0.3 & 1.0 & -88.4 \\
\hline -EU-27 & 2.9 & 3.2 & 1.6 & 0.9 & 1.7 & 1.7 & 1.3 & 1.0 & 1.1 & 0.8 & -72.4 \\
\hline \multicolumn{12}{|c|}{ 2.Unemployment rate, \% } \\
\hline -Lithuania & 4.2 & 5.8 & 13.7 & 17.8 & 15.4 & 13.2 & 11.8 & 10.7 & 9.1 & 7.9 & 85.7 \\
\hline -EU-27 & 7.1 & 6.9 & 8.9 & 9.6 & 9.6 & 10.5 & 9.5 & 10.2 & 9.4 & 8.6 & 21.1 \\
\hline \multicolumn{12}{|c|}{ 3. Discomfort index, $\%$} \\
\hline -Lithuania & 12.8 & 15.5 & 10.4 & 20.2 & 21.6 & 15.9 & 13.1 & 11.8 & 9.4 & 8.9 & -30.5 \\
\hline -EU-27 & 10.0 & 10.1 & 10.4 & 10.5 & 11.3 & 12.2 & 10.8 & 11.2 & 10.5 & 9.4 & -6.0 \\
\hline \multicolumn{12}{|c|}{ 4.People at risk of poverty of social exclusion, in $\%$ and 1000 persons } \\
\hline -Lithuania & 28.7 & 27.6 & 29.6 & 34.0 & 33.1 & 32.5 & 30.8 & 27.3 & 29.3 & 30.1 & 4.9 \\
\hline -EU-27 & 24.4 & 23.7 & 23.7 & 23.7 & 24.3 & 24.8 & 24.6 & 24.4 & 23.8 & 23.5 & 3.7 \\
\hline \multicolumn{12}{|c|}{ 5.Inequality of income distribution } \\
\hline -Lithuania & 5.9 & 5.9 & 6.4 & 7.3 & 5.8 & 5.3 & 6.1 & 6.1 & 7.5 & 7.1 & 20.3 \\
\hline -EU-27 & 5.0 & 5.0 & 5.0 & 5.0 & 5.1 & 5.1 & 5.0 & 5.2 & 5.2 & 5.2 & 4.0 \\
\hline
\end{tabular}

Not a very significant increase of risk of poverty occurred in EU-27 in the period of 2011-2012. The level of population inequality of income distribution shows that the ongoing economic and social policy is not efficient. The change of risk of poverty coefficient in Lithuania is compared with this index in the EU-27. The comparison shows, that the inequality of income distribution in the EU-27 is significantly lower than in Lithuania. In Lithuania the income differentiation after the economic crisis has dramatically increased from 5.9 in year 2008 to 7.3 in year 2010 and from 5.3 in year 2012 to 7.5 in year 2015. At the same time, the inequality of income distribution in the EU-27 shows positive economic and social policy changes during the post crisis period. 
The changes of social development indicators in the period 2007-2016 [28]

\begin{tabular}{|l|l|l|l|l|l|l|l|l|l|l|l|}
\hline Indicator/Year & $\mathbf{2 0 0 7}$ & $\mathbf{2 0 0 8}$ & $\mathbf{2 0 0 9}$ & $\mathbf{2 0 1 0}$ & $\mathbf{2 0 1 1}$ & $\mathbf{2 0 1 2}$ & $\mathbf{2 0 1 3}$ & $\mathbf{2 0 1 4}$ & $\mathbf{2 0 1 5}$ & $\mathbf{2 0 1 6}$ & $\begin{array}{l}\text { Growth } \\
\text { rate 2007- } \\
\mathbf{2 0 1 6} \%\end{array}$ \\
\hline $\begin{array}{l}\text { Unemploy-ment } \\
\text { rate, \% }\end{array}$ & 4.2 & 5.8 & 13.7 & 17.8 & 15.4 & 13.2 & 11.8 & 10.7 & 9.1 & 7.9 & 85.7 \\
\hline $\begin{array}{l}\text { Long term un- } \\
\text { employment } \\
\text { from total un- } \\
\text { employment, }\end{array}$ & $\ldots$ & 21.6 & 23.7 & 41.7 & 52.1 & 49.2 & 42.9 & 44.7 & 42.9 & 38.3 & 77.3 \\
\hline $\begin{array}{l}\text { Long term un- } \\
\text { employment, } \%\end{array}$ & $\ldots$ & 1.3 & 3.3 & 7.4 & 8.0 & 6.6 & 5.1 & 4.8 & 3.9 & 3.0 & 130.8 \\
\hline $\begin{array}{l}\text { Youth (16-25 } \\
\text { year) unemp- } \\
\text { loyment rate, } \%\end{array}$ & 8.4 & 13.6 & 18.4 & 34.6 & 32.6 & 26.7 & 21.9 & 19.3 & 16.2 & 14.5 & 72.6 \\
\hline
\end{tabular}

An important issue is the employment of the individual demographic groups and the unemployment rate, especially long-term unemployment, in the labor market of the country. Unemployment rate during the period of 2007-2016 in Lithuania increased from $4.8 \%$ to $7.9 \%$, i.e. increased by $85.7 \%$. It is important to note that long-term unemployment in Lithuania is significant, and in 2011 , it amounted up to $52.1 \%$ of the total unemployment rate of the country. Longterm unemployment in 2016 accounted for $38.3 \%$ of the total unemployment rate. Long-term unemployment in the year 2008-2016 increased to $130.8 \%$. The data show that youth unemployment rate is higher than the total unemployment rate throughout the analyzed period and in 2016 it amounted to $14.5 \%$. Scientific literature identifies various factors for the growth of unemployment, including youth, such as lack of professional qualifications and work experience, and the absence of a part of the youth "dropout" from the education system [17].

Scientific literature indicates that the decrease in unemployment rate is partly related to emigration of the population. After Lithuania's accession to the EU, changes in the emigration of the population are shown in Figure 1. The scientific literature analyzes the most common reasons for emigration [29]:

- free movement of workers;

- economic reasons;

- unemployment and wage differences;

- quality of life differences;

- social and cultural factors;

- studies abroad.

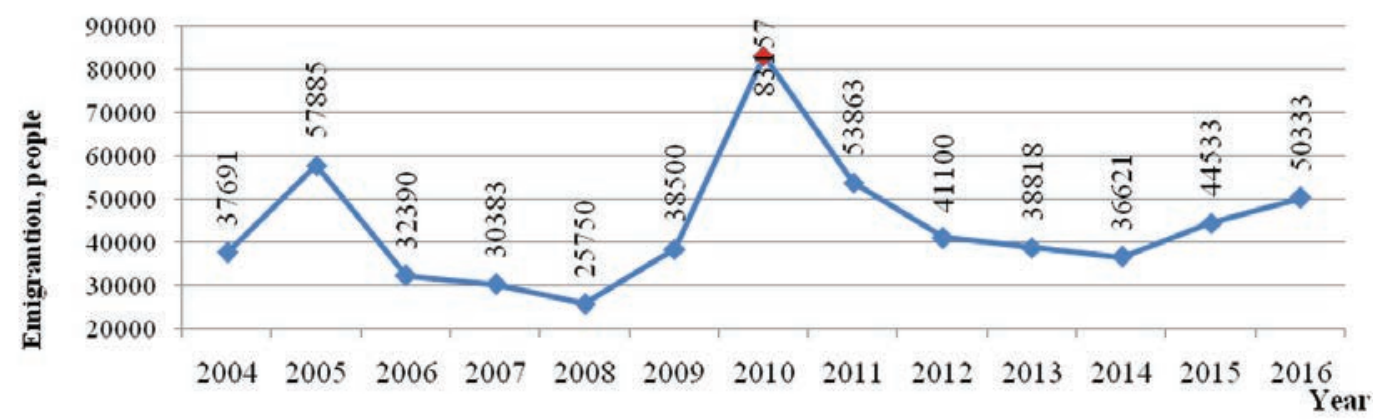

Fig.1. Emigration from Lithuania in the year 2004-2016, people [28]

Emigration flows in the period of 2007-2008 after Lithuania became a member of the EU in 2004, were the smallest. During the global financial crisis, emigration flows increased again and in 2010 were the largest - 83,157 inhabitants emigrate. During the period 2011-2014 the flow of emigration decreased, but during the period of 2015-2016 began to grow up again. Emigration level in 2016 compared to 2007 increased by $65.7 \%$. This process is most strongly encouraged by low incomes of the population, unemployment and limited social and economic policy of the country directed at solving social problems of the population due to the limited possibilities of the state budget. The minimum wage in Lithuania in 2016 in comparison with other EU countries is presented in Figure 2. In 2016 in Lithuania it was 380 EUR and was higher only than the minimum wage in Bulgaria. The minimum wage in the EU-27 was EUR 836, thus the minimum wage in Lithuania was $45.4 \%$ of the EU-27 minimum wage level. 


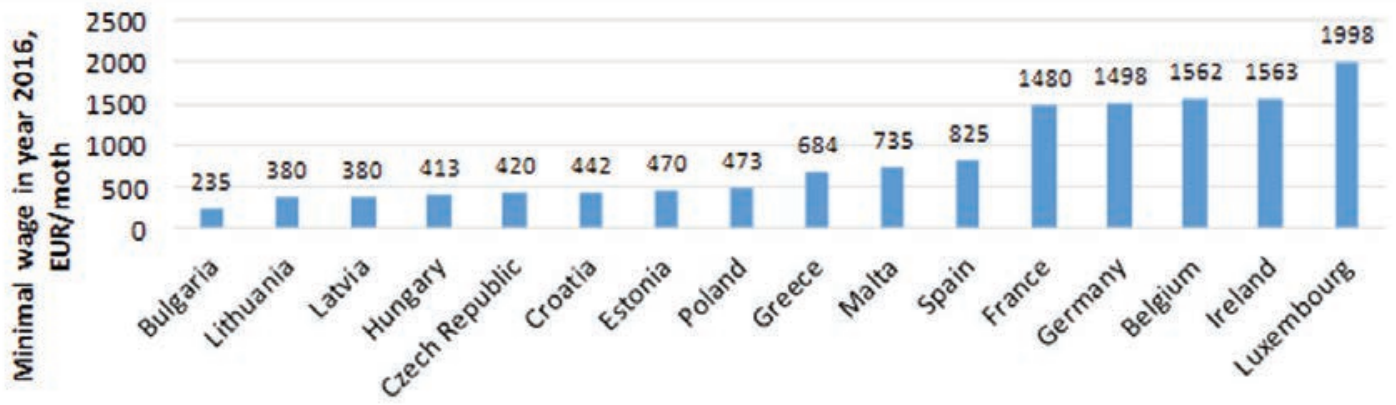

EU Member States

Fig.2. Minimum wage in Lithuania and others EU member states in the year 2016, EUR/month [28]

The changes of the average monthly earnings in Lithuania and the EU-27 in the period of 2010-2016 are given in the Fig.3.

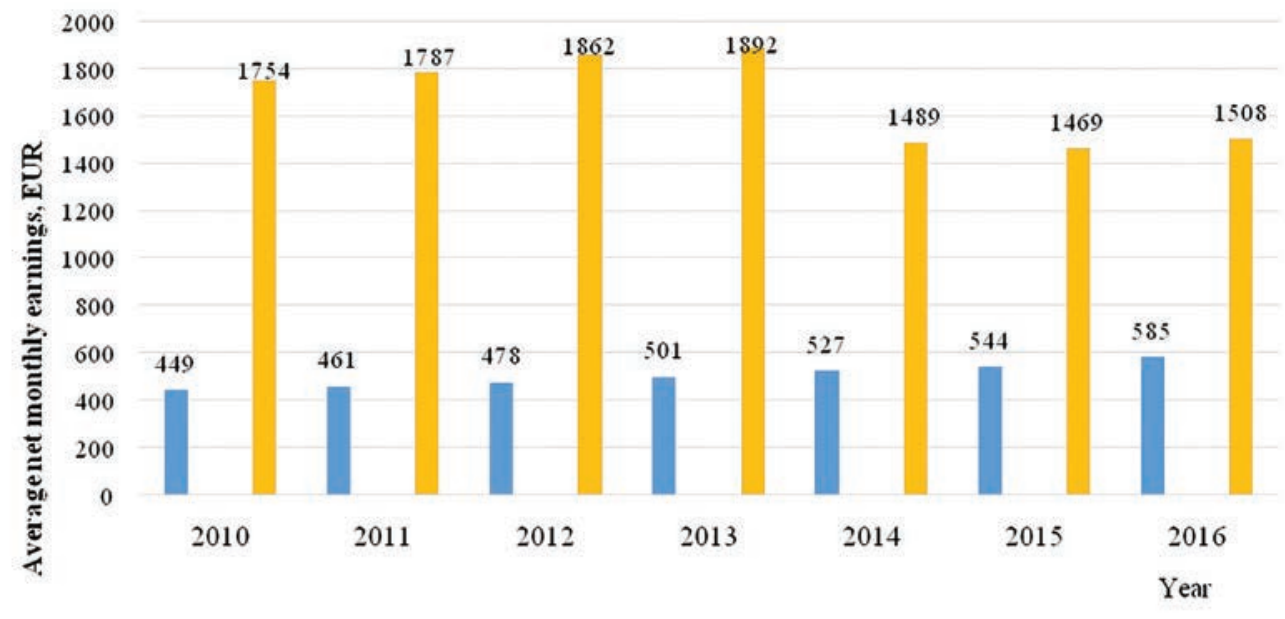

= Lithuania average net monthly earnings, EUR $\quad$ EU average net monthly earnings, EUR

Fig.3. Average net monthly earnings in Lithuania and EU-27 in the year 2010-2016, EUR [28]

The data show that in the period of 2010-2016 monthly net wages in Lithuania increased by 30.28\%. However, compared to the EU average in 2016, wages in Lithuania make only 38.8\%. Compared to the EU-27, the low average incomes of the population in Lithuania have an impact on poverty indicators and the need for social support.

\section{Conclusions}

The following results of our investigation were obtained:

- Threats, dangers to economic development adversely affect the outcome of the development of the country or region, and therefore need to be analyzed and measures taken to regulate them. Hazards are counterproductive to security and only a reduction in economic losses can ensure greater economic security in the country and achieve more robust economic growth. We argue that there is a need for comprehensive analysis of internal security threats in Lithuania. The main internal economic factors affecting country development are: unemployment and emigration,

- Economic development processes are often exposed not only to individual risks, but also to several closely related risks or so-called risk interactions that multiply negative outcomes. The main labor market indicators (unemployment, emigration and its structure), the transparency level of the country market (low level of employees in comparison with the EU average level, shadow economy share) reduce both budget revenues and both preconditions for national security in Lithuania;

- The research shows that internal indicators of economic development in Lithuania (unemployment level, emigration, low level of average net monthly earnings, minimal wage level) are important inside threats and dangers for the national security in Lithuania.

The observations above allow us to foresee that the determination of different aspects of challengers to national defense helps to discover new aspects, to enlarge the security of the country and to increase its competitiveness. 


\section{References}

1. Special Eurobarometer 432. European's attitudes towards security. Available: https://data.europa.eu/euodp /data/ dataset /S2085_83_2_432_ENG

2. Garbuz I. V. The transformation of the Russian economy in view of the current geopolitical risks. SGEM International Multidisciplinary Scientific Conferences on Social Sciences and Arts. Conference on Political Sciences Law, Finance, Economics \& Tourism. Conference Proceedings. Volume IV. Economics \& Tourism, September 1-10, 2014, Albena, Bulgaria. Instrumentation for trace detection of high explosives. Rev. Sci. Instrum, 2004, 75: 821-828.

3. Maciulis A., Tvaronaviciene M. Secure and sustainable development: Lithuania's new role in taking the presidency of the EU. Journal of Security and Sustainability Issues, 2013, Volume 3(2), p.5-13.

4. Vosylius E., Rakutis V., Tvaronaviciene M. Economic growth, sustainable development and energy security interrelat. Journal of Security and Sustainability Issues, 2013, Volume 2(3), p.5-14.

5. Melas V., Lisin E., Tvaronavičienė M., Peresadko G., Radwański, R. Energy security and economic development: renewable and the integration of energy systems. Journal of Security and Sustainability Issues, 2017, Volume 7 Number 1, p.134-139.

6. Lewandowski R. Economic sectors of strategic importance to the national security. A case of Poland. Equilibrium. Quarterly Journal of Economics and Economic Policy, 2016; VOLUME 11, ISSUE 3, p.473-497.

7. Smaliukienè R., Dudzevičiūtė G., Adekola A. F., Aktan B. The investigation of Lithuanian growth and industry export dependence on energetic resources. Journal of Security and Sustainability Issues, 2012, Volume 2(2), p.69-78.

8. Weill D. N. Economic Growth. 1st ed. 2005, Boston: Addison-Wesley. -547 p.

9. Romer D. Advanced macroeconomics. 4th ed. 2012, New York: McGrowHill Irwin. -550 p.

10. Williamson S.D. Macroeconomics. 6th ed. 2018, London: Pearson. -731 p.

11. Čiegis R., Ramanauskienè J. Integrated assessment of sustainable development: Lithuanian case, International Conference Research Papers. Management theory and studies for rural business and infrastructure development, Lithuania, 2011, No. 2(26), p. 30-42.

12. Starkevičiūtė M. Augimas ir iššūkiai. Lietuvos ekonomika 1990-2012 m. 2013, Kaunas: Technologija. -151 p.

13. Gylys P. Ekonomika, antiekonomika ir globalizacija. Monografija. 2008, Vilnius: Vilniaus universiteto leidykla. -443 p.

14. Ekonomikos modernizavimas. Efektyvumo paieškos ir šiuolaikiniai prioritetai. Sudarytojas ir mokslinis redaktorius Borisas Melnikas. 2011, Vilnius: Vilniaus universitetas. -539 p.

15. Kareivaitė R., Lipskis V., Rudytė, D. Ryšio tarp infliacijos ir nedarbo tyrimas Baltijos valstybėse. Ekonomika ir vadyba: aktualijos ir perspektyvos, 2007, 1 (8), p.134-142.

16. Moskvina J., Okuneviciute-Neverauskiene L. Aktyvi darbo rinkos politika: teorija ir praktika. Monografija. 2011, Vilnius: Technika. -256 p.

17. Pocius A. Demografinių grupių padèties pokyčiai Lietuvos darbo rinkoje irmetodinių skirtumų ịtaka santykiniams nedarbo rodikliams. Lietuvos statistikos darbai. Vilnius: Lietuvos statistikos departamentas, 2016, 55 t., Nr 1, p. 6-18.

18. Zabarauskaitė R., Blažienė I. Gyventojų pajamų nelygybė ekonominių ciklų kontekste. Verslas: teorija ir praktika, 2012, 13(2), p.107-115.

19. Skučienė D. Pajamų nelygybė: senatvès pensijų vaidmuo. Lietuvos socialinė raida, 2015, Nr. 4, p.88-103.

20. Gataulinas A. Dirbančiųjų skurdas Lietuvoje ES kontekste: socialinės ir demografinès priežastys. Lietuvos socialinė raida, 2015, Nr. 4, p.75-87.

21. Lazutka R., Gruževskis B., Kondrotienè S., Ilgius V., Sakadolskis R. Projekto „Telkiamès skurdo mažinti“ metodika: skurdas ir socialinè atskirtis, lèšų telkimas, advokacija, komunikacija. 2013, Vilnius. -125 p. Prieiga per internetą: http://stopskurdas.lt/downloads/pts-metodika.pdf

22. Lydeka Z., Bradauskas V. Korupcijos lygio poveikio šešèlinės ekonomikos paplitimo mastui vertinimas. Taikomoji ekonomika: sisteminiai tyrimai, 2016, T. 10, Nr.2, p.13-30.

23. Maksvytienė I., Valuckaitè I. Šešèlinès ekonomikos priežasčių Lietuvoje vertinimas. Taikomoji ekonomika: sisteminiai tyrimai, 2017, T. 11, Nr. 1, p.27-37.

24. Szu Ping Chan. Here are the five biggest risks facing the global economy. Business: news and comments, 2017, January 11, p.1-2.

25. World Economic Forum. Global Risks Perception Survey 2016. Appendix B: Global Risks Perception Survey and Methodology 2016. Available: http://reports.weforum.org/global-risks-2017/part-1-global-risks-2017

26. World Economic Forum The Global Risks. Report 2017. 12 th ed. 2017, Geneva. -78p.

27. The World Bank Group Data. World Bank Data. World development Indicators, 2014. Available: http://www.databank. worldbank.org/data/views/reports/tablview.aspx

28. Lietuvos statistikos departamentas. Oficialiosios statistikos duomenys. Prieiga per internetą: https://osp.stat.gov.lt/

29. Rakauskienė G., Ranceva O. Youth Unemployment and Emigration Trends. Intelektinè ekonomika. Intellectual economics, 2014, Vol. 8, No. 1(19), p.165-177 